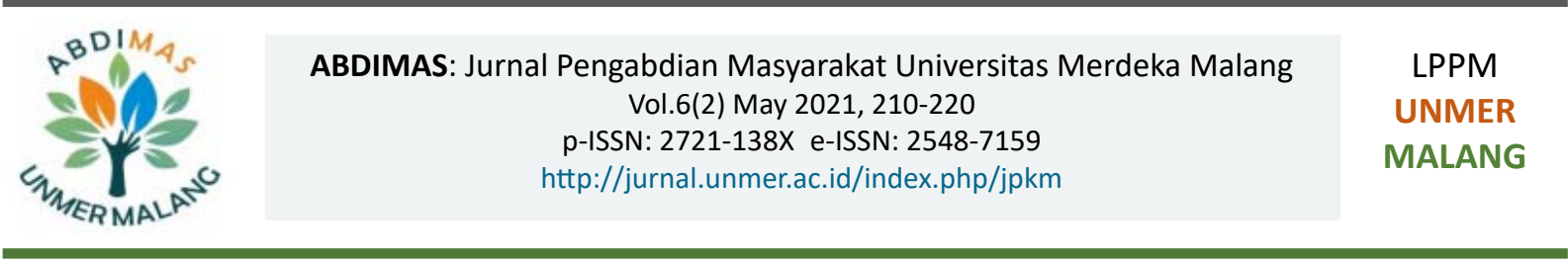

\title{
Menggali Potensi Ekonomi Kreatif sebagai Sarana Pendukung Desa Wisata
}

\author{
Diyah Sukanti Cahyaningsih", Tonny Suhartono², Sri Widayati ${ }^{3}$ \\ 'Departemen Akuntansi Fakultas Ekonomi dan Bisnis, 2Departemen Teknik Arsitektur Fakultas Teknik, ${ }^{3}$ Departemen \\ Komunikasi Fakultas Ilmu Sosial dan Ilmu Politik, Universitas Merdeka Malang \\ Jl. Terusan Raya Dieng No.62-64 Malang, 65146, Indonesia
}

ARTICLE INFO
Received: 2020-11-26
Revised: 2021-01-05
Accepted: 2021-02-26
Keywords:
Creative economy,
Homestays, Special
food souvenirs, Tourist
villages

\section{ABSTRACT}

Creative economy development in tourist villages is very important. In supporting the existence of a tourist village, homestays and special food souvenirs are the carrying capacity. Study of economic benefits is needed to strengthen the motivation of citizens in developing this creative economy. This Homestay service aims to provide a new source of income for the family. The Community Service Team organizes activities in several stages by prioritizing citizen participation. The service method used is the Community Based Development or Participatory Approach. This method is used to ensure the commitment of citizens to this economic empowerment program. With the participation of residents who are the basis of this program, it is believed that the program will continue after the mentoring period ends. The result of this dedication is the first, the arrangement of the house into a homestay with the category of "in-house". The housing facilities were tidied up and equipped for the benefit of tourists, but did not leave the typical life of the residents as the main attraction. Second, management of typical food packages and chips souvenirs. Residents are given a discourse to make culinary packages that are marketed online to be ordered by prospective tourists who will visit. Taro chips, which are one of the household activities that have been managed in a simple manner, are directed towards better and more attractive management and packaging. In the final stage, an economic study of the homestay and taro chips business is given to calculate the future development of this business.

(C) 2021 Published by University of Merdeka Malang. This is an open access article distributed under the CC BY-SA 4.0 license (https://creativecommons.org/licenses/by-sa/4.0/)

How to cite: Cahyaningsih, D. S., Suhartono, T., \& Widayati, S. (2021). Menggali Potensi Ekonomi Kreatif sebagai Sarana Pendukung Desa Wisata. Abdimas: Jurnal Pengabdian Masyarakat Universitas Merdeka Malang, 6(2), 210-220. https://doi.org/10.26905/abdimas.v6i2.5078

\section{PENDAHULUAN}

Dusun Grangsil terletak di Desa Jambangan, Kecamatan Dampit, Kabupaten Malang. Dusun ini memiliki keunggulan sumber daya alam, tanahnya yang subur dimanfaatkan sebagian besar warga untuk bertani bunga (Wikantiyoso et al., 2019). Kebun bunga merupakan potensi ekonomi sekaligus potensi wisata. Sejak ditetapkan sebagai Desa Wisata di tahun 2019, Kampoeng Boenga Grangsil terus berbenah diri. Homestay adalah salah satu wujud ekonomi kreatif desa wisata, karena keberadaannya 


\section{Menggali Potensi Ekonomi Kreatif sebagai Sarana Pendukung Desa Wisata}

Diyah Sukanti Cahyaningsih, Tonny Suhartono, Sri Widayati

akan memberi peluang bagi peningkatan pendapatan keluarga. Homestay dalam kawasan desa wisata diharapkan memberikan dampak: (1) Peningkatan pertumbuhan ekonomi; (2) Pelestarian budaya lokal; (3) Menjaga harmoni antara alam dan lingkungan (Kementerian Pariwisata Republik Indonesia, 2018). Konsep ekonomi kreatif mengusung dampak ekonomi sekaligus budaya, cermin nilai kearifan lokal, dan ekonomi lokal tercermin pada produk kreatif. Penelitian dan survei yang pernah dilakukan sebelumnya memberikan hasil bahwa potensi ekonomi Indonesia sangat didukung oleh industri kreatif dan pariwisata (Lembaga Penyelidikan Ekonomi dan Masyarakat FEB Universitas Indonesia, 2018). Pada tahun 2002 Indonesia menduduki posisi 6 Dunia (UNCTAD, 2018). Namun UNCTAD (2018) juga menunjukkan hasil survei untuk kategori "personal, cultural, and recreational services" yang dimana Indonesia belum berkontribusi. Hal tersebut dimungkinkan terjadi karena maraknya desa wisata di Indonesia sejak sekitar tahun 2000 yang belum terdata dengan baik dan belum terpublikasi. Dari sisi konsep keunggulan destinasi wisata, hendakya Kampoeng Boenga Grangsil dapat memenuhi 4 hal yaitu atraksi, aksesibilitas, amenitas, dan ansilari (Antara \& Arida, 2015). Pada konsep amenitas, Kampoeng Boenga Grangsil belum memiliki sarana penginapan, maka dengan potensi yang ada inilah pengabdi ingin mengembangkan desa wisata ini dengan keberadaan homestay dan pengembangan kuliner sebagai penunjang ekonomi kreatif lokal. Pengembangan desa wisata ini bertujuan untuk melengkapi standar sebuah destinasi wisata yang merupakan hal mutlak dilakukan untuk menjaga kestabilan frekuensi kunjungan wisatawan (Henderson, 2007).

Konsep homestay ini mengacu pada panduan homestay desa wisata yang diluncurkan Kementerian Pariwisata dan Ekonomi Kreatif dengan penyesuaian kondisi masyarakat yang ada. Mengingat kekhasan desa dan suasana pedesaan menjadi potensi tersendiri untuk diusung dalam destinasi wisata ini. Definisi homestay yang dibina oleh Kementerian Pariwisata adalah: (1) Rumah yang dimiliki warga lokal; (2) Dikelola perorangan atau komunitas; (3) Pemasaran oleh Pokdarwis, Bumdes, atau Kementerian Pariwisata (Kementerian Pariwisata Republik Indonesia, 2018). Homestay yang dimaksud dalam pengabdian ini adalah pondok inap, merupakan tempat menginap wisatawan yang menyatu dengan kegiatan rumah tangga. Nilai lebih yang diharapkan dari homestay jenis ini adalah wisatawan dapat ikut menikmati kehidupan desa secara langsung sebagaimana dalam Antara \& Arida (2015) menjelaskan bahwa "...Destinasi berkaitan dengan sebuah tempat atau wilayah yang mempunyai keunggulan dan ciri khas, baik secara geografi maupun budaya, sehingga dapat menarik wisatawan untuk mengunjungi dan menikmatinya...". Mendapatkan pengalaman yang berbeda dan kenangan untuk menarik kunjungan kembali di masa yang akan datang. Pada kondisi Kampoeng Boenga Grangsil yang masih akan mengawali adanya homestay melalui pengabdian ini, alternatif homestay jenis pondok inap sangat memungkinkan. Selain dari aspek biaya pengadaan yang murah, cukup dilakukan perbaikan dan penataan saja tanpa membangun baru. Pemilik rumah sekaligus pengelola homestay tidak perlu meninggalkan rumah dalam mengelolanya. Potensi anggota keluarga dapat menjadi pendukung usaha, misalnya keterampilan mengolah makanan atau kerajinan tangan. Karena rumah dapat berfungsi sekaligus sebagai ruang pamer hasil usaha.

Kuliner adalah satu dari lima belas sub sektor ekonomi kreatif yang dikembangkan oleh Kementerian Pariwisata dan Ekonomi Kreatif. Kuliner meliputi kegiatan secara menyeluruh mulai dari persiapan, pengolahan, penyajian produk makanan pokok, makanan ringan, dan juga minuman. Keunggulan citarasa, kreasi, dan estetika menjadi daya tarif sub sektor ini. Kendala pengembangan sub sektor kuliner adalah kualitas sumber daya manusia yang belum terdata dengan baik, potensi alam yang belum 
ABDIMAS: Jurnal Pengabdian Masyarakat Universitas Merdeka Malang

Volume 6, No 2, May 2021: 209-220

teridentifikasi dan belum terjaga kelestariannya dalam menjaga warisan budaya kuliner (Lazuardi \& Triady, 2015). Kurangnya sarana dan pemanfaatan media sosial sebagai sarana promosi juga belum optimal. Konsep kuliner sebagai pengembangan potensi ekonomi kreatif dalam pengabdian ini tidak lepas dari keberadaan homestay. Pengembangan kuliner di tempat wisata adalah sebuah sinergi yang saling melengkapi dalam mengangkat popularitas destinasi wisata (Sari, 2018). Warga yang didampingi dalam penyediaan homestay diupayakan untuk mengusahakan kuliner setidaknya menyediakan menu makanan sehari-hari yang dapat dijual pada tamu wisatawan. Makanan khas atau lauk khas daerah ini diangkat sebagai icon yang dapat menarik minat berkunjung. Menggali potensi kuliner dan sekaligus memasarkan melalui media sosial diyakini akan memberi dampak peningkatan ekonomi warga Yusadi et al., 2018). Harapan dari pengabdian ini adalah memberikan pendampingan yang menyeluruh, dari potensi homestay, potensi kuliner, dan meramunya dalam kemasan wisata yang dipasarkan dalam media sosial, mengingat media sosial adalah ajang promosi yang memiliki dampak cukup signifikan dalam peningkatan kunjungan wisata (Hamzah, 2013).

\section{METODE}

Ketika masyarakat menjadi subjek dalam suatu pengabdian atau riset, perludilakukan pemberdayaan dan penyiapan masyarakat dengan konsep Community Based Development atau Participantry Approach (Campbell \& Vainio-Mattila, 2003). Pengabdian ini dilaksanakan dengan pendekatan partisipatif dimana partisipasi masyarakat merupakan prasyarat penting dalam upaya pemberdayaan atau pembangunan. Tanpa partisipasi masyarakat justru akan memarginalkan masyarakat itu sendiri (Lazuardi \& Triady, 2015).

Untuk memahami kebutuhan objek pengabdian dengan lebih baik, pengabdi melakukan survei terlebih dahulu untuk memahami kondisi lapangan. Survei melibatkan kedua belah pihak, baik wisatawan maupun warga selaku tuan rumah dari destinasi wisata. Dari hasil survei pengabdi membuat simpulan sementara kondisi objek pengabdian dan melakukan sosialisasi pengamatan awal ini untuk mendapatkan respon warga. Gambar 1 berikut merangkum sasaran dalam pendampingan berbasis partisipasi masyarakat ini. Pengabdian ini harus meletakkan masyarakat sebagai objek seutuhnya yang menyatu dengan linkungannya. Pada desa wisata, peran manusia, sarana, dan juga kearifan lokal menjadi satu kesatuan yang tidak terpisahkan (Soekarya, 2011).

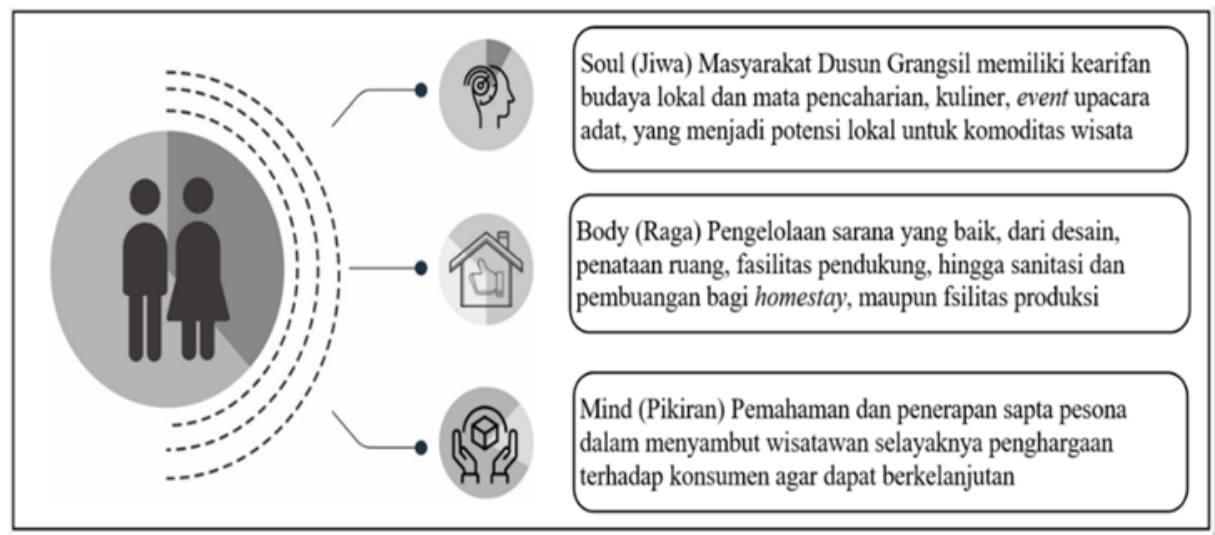

Gambar 1. Konsep homestay sebagai bagian dari masyarakat Kampoeng Boenga Grangsil 
Langkah berikutnya, berdasarkan curah pendapat dari warga adalah pengabdi mengambil 3 objek yang paling memungkinkan untuk dijadikan percontohan homestay dan memilih satu pengrajin keripik talas untuk didampingi. Mengingat masa pengabdian cukup singkat dan perkembangan destinasi wisata ini nantinya diharapkan akan lebih besar, maka untuk mewujudkan pendampingan berkelanjutan, pengabdi menyajikan perhitungan kelayakan usaha sebagai model untuk pengembangan usaha warga di masa yang akan datang.

\section{HASIL DAN PEMBAHASAN}

Dalam melakukan pengabdian dengan pendekatan partisipasi masyarakat, maka pengabdi membagi kegiatan dalam beberapa tahap berikut.

Tahap survei presepsi wisatawan dan kelayakan pendirian usaha homestay

Tim Pengabdi melakukan survei terhadap pengunjung dan memperoleh data seperti yang tertera dalam Tabel 1.

Tabel 1. Survei persepsi wisatawan

\begin{tabular}{|c|c|c|}
\hline Kriteria & Indikator & Rata-rata Presepsi \\
\hline Atraksi & $\begin{array}{l}\text { - Wisata edukasi bunga } \\
\text { - Atraksi tradisional }\end{array}$ & $\begin{array}{l}\text { Sangat Cukup } \\
\text { Kurang }\end{array}$ \\
\hline Aksesbilitas & $\begin{array}{ll}\text { - } & \text { Ada sarana angkutan umum } \\
\text { - } & \text { Lokasi mudah dicari (Google Maps) } \\
\text { - } & \text { Terjangkau kendaraan roda } 2 \text { dan roda } 4\end{array}$ & $\begin{array}{l}\text { Sangat Kurang } \\
\text { Cukup } \\
\text { Cukup }\end{array}$ \\
\hline Amenitas & $\begin{array}{ll}\text { - } & \text { Sarana jalan yang memadai } \\
\text { - } & \text { Listrik } \\
\text { - } & \text { Jaringan telepon selular yang stabil }\end{array}$ & $\begin{array}{l}\text { Kurang } \\
\text { Cukup } \\
\text { Kurang }\end{array}$ \\
\hline
\end{tabular}

Tim Pengabdi melakukan survei terhadap warga yang berpotensi untuk mendirikan homestay dan mendapatkan data seperti yang tertera dalam Tabel 2.

Tabel 2. Survei kelayakan pendirian homestay

\begin{tabular}{|c|c|c|}
\hline Kriteria & Indikator & Rata-rata Presepsi \\
\hline \multirow{2}{*}{$\begin{array}{l}\text { Legalitas untuk keamanan (khusus } \\
\text { untuk renovasi dan pendirian baru) }\end{array}$} & - Legalitas hak atas tanah & Memenuhi \\
\hline & - Peruntukan lahan & Memenuhi \\
\hline \multirow[t]{2}{*}{ Kesiapan Masyarakat } & $\begin{array}{l}\text { - Pemilik dan pengelola memahami pelestarian } \\
\text { lingkungan dan Budaya setempat }\end{array}$ & Sangat memenuhi \\
\hline & - Pemilik dan pengelola memahami sapta pesona & Cukup \\
\hline Luas lahan & - Luas lahan minimal $60 \mathrm{~m}^{2}$ dan bangunan $36 \mathrm{~m}^{2}$ & Memenuhi \\
\hline
\end{tabular}

Potensi Wisata Kampoeng Boenga Grangsil sangat beragam. Berawal dari mata pencaharian sebagian besar warga Dusun Grangsil sebagai petani bunga, memunculkan kesempatan wisata belanja 
ABDIMAS: Jurnal Pengabdian Masyarakat Universitas Merdeka Malang Volume 6, No 2, May 2021: 209-220

bunga. Selain tampilan dari greenhouse dengan aneka macam bunga di dalamnya yang menjadi daya tarik, kebun bibit bunga dapat dimanfaatkan sekaligus sebagai wahana edu-wisata tanam bunga. Potensi ini sangat bermanfat dalam memberikan wadah pembelajaran siswa SD atau anggota Pramuka dalam tema pembelajaran lingkungan hidup. Di dusun ini juga terdapat potensi pertanian sayur dan kopi. Selain itu, masyarakat juga memiliki warisan budaya berupa upacara adat tahunan dan kesenian "bantengan", sebuah kelompok tari tradisional dengan ritual tertentu yang ditampilkan dalam kegiatan tradisional rutin warga. Sangat disayangkan jika potensi tersebut tidak dikembangkan. Sebagaimana daerah pertanian pada umumnya, kondisi udara di daerah ini sangat bersih dan sejuk, wisatawan akan tertarik untuk tinggal lebih lama, jika fasilitasnya mendukung. Rencana pengembangan untuk melengkapi desa wisata ini dengan homestay dan memberikan kenangan berupa oleh-oleh makanan adalah sangat layak. Potensi utama Kampoeng Boenga Grangsil dapat dilihat dari Gambar 2.
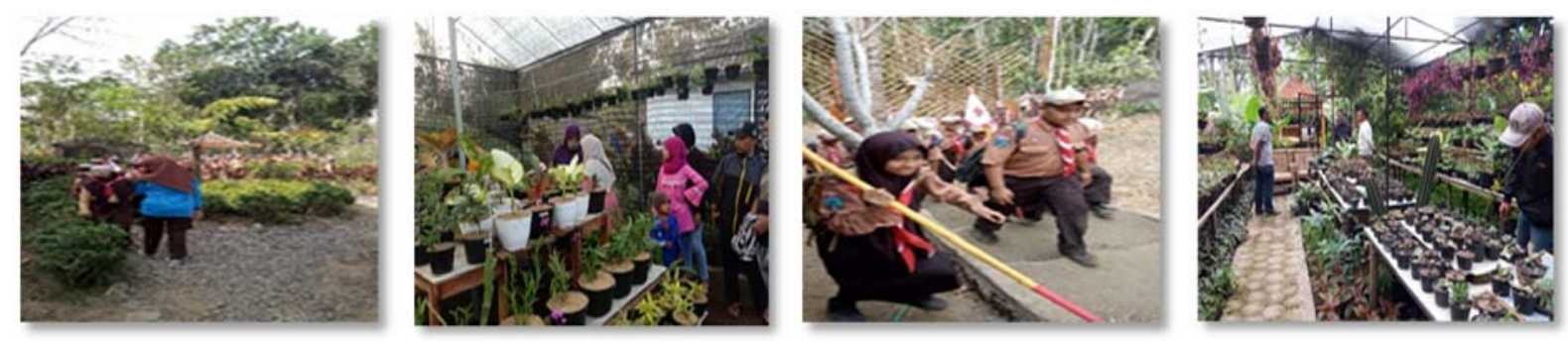

Gambar 2. Potensi wisata Kampoeng Boenga Grangsil

\section{Aplikasi hasil survei terhadap objek pengabdian}

Dari data yang diperoleh pada tahap survei, tim pengabdi melakukan curah pendapat bersama warga. Hal tersebut bermanfaat untuk mengurangi efek bias dari hasil survei dan lebih menggali presepsi masyarakat. Partisipasi masyarakat ini sangat penting mengingat aspek dalam pengelolaan desa wisata melibatkan aspek budaya lokal sebagai jiwa dari masyarakat, dan peran pemikiran masyarakat yang berperan sebagai tuan rumah dari para wisatawan. Kegiatan ini didokumentasikan pada Gambar 3.

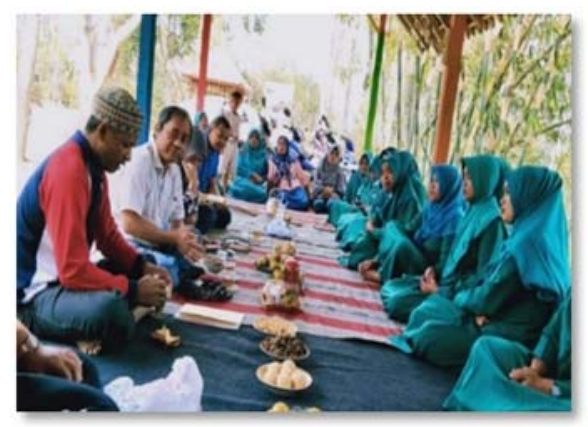

Gambar 3. Curah pendapat melibatkan Pokdarwis dan PKK 


\section{Menggali Potensi Ekonomi Kreatif sebagai Sarana Pendukung Desa Wisata \\ Diyah Sukanti Cahyaningsih, Tonny Suhartono, Sri Widayati}

\section{Simulasi kegiatan}

Dari hasil curah pendapat, dipilih 3 rumah sebagai objek dan dilakukan penataan homestay dengan kriteria pondok inap. Kriteria pemilihan adalah berdasarkan tingkat kesiapan konsep pada tabel di atas. Pemilik rumah yang dijadikan objek memiliki pemahaman yang cukup baik tentang potensi lokal, ketersediaan ruang di dalam rumahnya yang cukup, dan kesiapan untuk melayani wisatawan. Ada beberapa penyempurnaan objek pengabdian untuk menjadi pondok inap yang mengacu pada standar Kementerian Pariwisata. Sarana utama antara lain, pintu yang awalnya berupa gorden dipasang pintu permanen, memasang dan memperbaiki instalasi lampu, saklar, dan stop kontak yang ada di dalam kamar, serta penyempurnaan ventilasi udara. Sarana penunjang diantara lain, matras yang memadai, sprei yang bersih, perlengkapan mandi, dan penataan ruang tamu, penataan halaman. Pembekalan guiding dan tatalaksana penerimaan tamu wisata juga diberikan sebagai pelangkap yang dirasa sangat penting.

Untuk potensi kuliner makanan utama, dipilih menu makanan ringan yang dapat dikemas untuk oleh-oleh yaitu keripik talas. Pemilihan ini berdasarkan hasil wawancara dengan warga yang mengemukakan keunggulan produk ini. Beberapa alasan pemilihan keripik talas antara lain karena bahan dasarnya mudah ditemui di Kawasan Desa Jambangan, pengolahannya sangat mudah, dan biaya produksi terhitung cukup murah untuk oleh-oleh khas Grangsil. Pendampingan meliputi standar kebersihan pengolahan dan pengemasan produk. Pengemasan sederhana yang dilakukan warga sebelumnya diarahkan untuk pengemasan yang lebih sesuai dengan standar kemasan makanan. Mengingat pada produk olahan makanan, pengemasan yang lebih baik akan berdampak pada higienitas dan keawetan produk. Bahkan untuk jenis bahan kemasan, plastic foodgrade dan aluminium foil memiliki klasifikasi ijin pengemasan yang berbeda dari departemen Kesehatan. Kemasan juga menjadi daya tarik tersendiri bagi calon konsumen (Rofieq et al., 2017).


Gambar 4. Penyerahan sarana kelengkapan homestay dan penataanya

\section{Pembahasan}

Kajian homestay dan oleh-oleh keripik talas sebagai perwujudan ekonomi kreatif desa wisata sangat diperlukan di akhir tahapan pengabdian. Menelaah tahapan pengabdian di atas melalui tahapan studi kelayakan yang secara sederhana. Kajian ini disampaikan dalam pendampingan, dengan tujuan memberikan gambaran tentang kelayakan kedua jenis usaha kreatif ini kepada warga. 
ABDIMAS: Jurnal Pengabdian Masyarakat Universitas Merdeka Malang

Volume 6, No 2, May 2021: 209-220

\section{Aspek pasar dan pemasaran}

Aspek pasar dan pemasaran meliputi permintaan pasar dan minat pasar. Sebagaimana telah dilakukan pada tahapan pertama pengabdian, minat pasar yaitu wisatawan terhadap keberadaan homestay dan adanya oleh-oleh khas yang cukup tinggi didukung bahan baku talas yang sangat banyak.

\section{Pesaing}

Homestay dengan kategori pondok inap ini memiliki kecenderungan permintaan yang tinggi pada masa libur atau akhir pekan. Sementara beberapa keluarga memiliki pola berkumpul keluarga di akhir pekan. Maka tingkat persaingan antar warga dalam mendapatkan tamu wisata sementara ini, relatif rendah. Sedangkan untuk produk oleh-oleh, persaingannya juga belum nampak, mengingat masih sedikit jumlah warga yang terlibat. Namun di masa yang akan datang, diharapkan persaingan yang semakin tinggi dapat ditunjang permintaan pasar yang makin banyak untuk menyeimbangkannya.

\section{Pangsa pasar}

Pada masa pandemik 2020 ini, pangsa pasarcenderung kurang. Namun kedepannya, dengan harapan kondisi kesehatan semakin membaik, ada pangsa pasar potensial yang bisa dibidik yaitu kegiatan live-in siswa siswi Sekolah Menengah di Malang Raya Kegiatan live-in ini sebelum masa pandemik menjadi agenda rutin tahunan dari berbagai SMP/SMA di Kota Malang, peluang Kampoeng Boenga Grangsil untuk diminati sebagai destinasi kegiatan tersebut cukup besar. Untuk oleh-oleh keripik talas, selama ini pemasaran sangat terbatas, dengan peningkatan kunjungan wisata di masa yang akan datang, diharapkan menjadi pasar yang potensial untuk menjadi konsumen sekaligus agen promosi ke luar daerah Malang.

\section{Strategi dan bauran pemasaran}

Bauran Pemasaran yang terdiri dari product, price, place, dan promotion. Pada konsep homestay ini lebih mengedepankan kesiapan ruang inap dan sarana penunjangnya serta adanya oleh-oleh. Hal tersebut akan menentukan kepantasan harga, semakin baik kondisi ruang maka semakin pantas menetapkan harga tinggi. Untuk promosi, media sosial dapat menjadi sarana yang murah dan mudah memperkenalkan keberadaan homestay dan kudapan ringan khas Dusun Grangsil tersebut. Mengingat pengembangan pemasaran melalui Web Commerse dengan didukung tampilan profil desa yang menarik merupakan akan menjadi daya dukung pemasaran yang sangat baik (Widayati et al., 2019).

\section{Aspek teknis dan produksi}

Untuk jenis usaha homestay teknik dan produksi adalah penataan ruang dengan standar perbaikan seperti: (1) Mengatur layout ruang yang memenuhi standar luas, ventilasi, dan privacy; (2) Memastikan aliran listrik/ penerangan dan keamanan kamar; (3) Menata kamar dengan tampilan yang bersih dan indah; (4) Menata Kesiapan kamar mandi; (5) Kelengkapan lain pendukung. 
Untuk produk keripik talas ini, aspek produksi di upayakan mengikuti standar produksi makanan olahan dan masih dalam proses untuk dibantu didaftarkan regiter produksinya ke Dinas Kesehatan setempat.

\section{Aspek organisasi dan manajemen}

Aspek organisasi dan manajemen meliputi: (1) Struktur organisasi. Sementara ini, pemilik homestay atau pengrajin keripik adalah sekaligus pengelola, namun untuk keseragaman pelayanan dan produksi yang baik, perlu melibatkan Pokdarwis dan PKK sebagai koordinator. Fungsi organisasi ini untuk standarisasi pelayanan homestay, proses produksi dan pengemasan keripik serta penetapan harga; (2) Jumlah dan kualifikasi tenaga kerja. Untuk usaha berbasis rumah tinggal, anggota keluarga adalah bagian dari tenaga kerja. Anggota keluarga terlibat dalam kegiatan pelayanan wisata bagi para tamu.

\section{Aspek finansial homestay}

Aspek finansial homestay yang pertama adalah kebutuhan dana. Tabel 1 merupakan gambaran kebutuhan dana standar 1 kamar pada pondok inap dengan asumsi, ruang telah tersedia di rumah, namun belum tertata, dan memerlukan renovasi yang tidak besar.

Tabel 3. Kebutuhan dana standar 1 kamar pondok inap

\begin{tabular}{lc}
\hline \multicolumn{1}{c}{ Bentuk Pengeluaran } & Harga (Rp) \\
\hline Pengecatan Kamar ukuran $3 \times 3 \mathrm{~m}$ & 450.000 \\
Pengadaan matras standar ukuran $160 \times 200 \mathrm{~cm}$ & 900.000 \\
Sprei polos ukuran $160 \times 200$ dan selimut & 350.000 \\
Pengecatan Kamar Mandi $2 \times 1 \mathrm{~m}$ & 300.000 \\
Peralatan mandi untuk persediaan (sabun, pasta gigi, sikat gigi, dan handuk) & 200.000 \\
Pengeluaran lain-lain & 150.000 \\
\hline Total & 2.250 .000 \\
\hline
\end{tabular}

Aspek kedua adalah sumber dana. Di luar kegiatan pengabdian, sumber dana berasal dari swadaya pemilik rumah. Dari hasil curah pendapat dengan warga, jumlah tersebut tidak terlalu besar, mengingat kebiasaan warga tiapa tahun merawat rumah mereka dengan pengecatan. Perhitungan modal kerja menggunakan metode konvensional payback period. Perhitungan ini akan mengukur lama pengembalian modal. Dirumuskan dalam Eq. (1).

$\mathrm{PP}=($ Total Investment : Cash Flow per tahun) $\times 1$ tahun

Dengan perkiraan hunian tetap 2 hari per bulan dan standar tarif inap per orang Rp. 50.000; tanpa menyediakan makan, maka diperoleh hasil sebagai berikut.

$\mathrm{PP}=(2.250 .000: 1.200 .000 /$ th $) \times 1$ th $=1,875$ tahun, atau 1 tahun 11 bulan 
ABDIMAS: Jurnal Pengabdian Masyarakat Universitas Merdeka Malang

Volume 6, No 2, May 2021: 209-220

Jangka waktu pengembalian di atas dianggap sangat layak, apalagi dengan harapan kondisi pandemik segera berlalu, tingkat hunian bisa lebih tinggi, sehingga pengembalian investasi lebih cepat.

\section{Aspek finansial keripik talas}

Tabel 4. Perhitungan harga pokok produksi $10 \mathrm{~kg}$ Keripik talas siap kemas

\begin{tabular}{lr}
\hline \multicolumn{1}{c}{ Jenis Bahan } & Harga (Rp) \\
\hline Bahan baku dan bumbu & 35.000 \\
Minyak goreng & 22.500 \\
Kemasan & 60.000 \\
Jumlah & 117.500 \\
Dibagi menjadi 40 kemasan @250 gram & $2.397,5$ \\
\hline
\end{tabular}

Sumber dana pembuatan keripik talas berasal dari biaya pribadi pengrajin dengan omset kemampuan produksi $25 \mathrm{~kg}$ per minggu. Sedangkan perhitungan modal kerja menggunakan metode konvensional payback period. Perhitungan ini akan mengukur lama pengembalian modal. Total investasi dihitung dari penjumlahan asset tetap produksi dan harga pokok produksi rata-rata tahunan. Dirumuskan dengan Eq. (1) dengan perkiraan penjualan 40kg/bulan seharga Rp. 25.000/kg.

$\mathrm{PP}=(4.377 .000: 12.000 .000 /$ th $) \times 1$ th

$=0.36$ tahun, atau kurang lebih 4 bulan 30 hari

Perhitungan di atas dapat memberikan gambaran kepada warga yang ingin mengembangkan homestay, atau membuka usaha produiksi keripik sampai jangka waktu berapa lama investasi yang mereka tanamkan akan kembali. Jangka waktu pengembalian di atas dianggap sangat layak.

\section{SIMPULAN DAN SARAN}

Dari rangkaian kegiatan pengabdian telah diperoleh data partisipasi warga yang sangat mendukung program pendirian homestay berbasis rumah tinggal di Kampoeng Boenga Grangsil dan pengembangan usaha oleh-oleh keripik talas. Kesadaran warga untuk memperkuat potensi wisata di desa ini sangat tinggi. Kehadiran warga pada tiap pertemuan dan pembahasan kegiatan menjadi tolak ukur kesiapan warga untuk menerima program ini dan mengembangkannya ke depan. Begitupula dukungan kelompok sadar wisata dan PKK yang menjadi wadah organisasi homestay ini.

Berdasarkan kajian ekonomi yang ada, menunjukkan potensi keberhasilan yang cukup baik di masa yang akan datang. Maka diharapkan pada masa yang akan datang warga dapat: (1) Menambah jumlah homestay; (2) Menciptakan daya tarik pada masing-masing hunian melalui produk olahan makanan; dan (3) Mampu menambah pendapatan keluarga dan meningkatkan kesejahteraan masyarakat desa. Bagi pengabdi selanjutnya, hasil pengabdian ini dapat menjadi prototype kegiatan pemberdayaan ekonomi desa wisata, dan dapat dikembangkan pada daya tarik desa setempat yang belum dikembangkan. 


\section{Menggali Potensi Ekonomi Kreatif sebagai Sarana Pendukung Desa Wisata}

Diyah Sukanti Cahyaningsih, Tonny Suhartono, Sri Widayati

Misalnya kegiatan merangkai bunga atau edukasi pembuatan pupuk kompos, untuk menambah aktivitas wisatawan saat menginap.

\section{UCAPAN TERIMA KASIH}

Pelaksanaan Pengabdian ini didanai oleh Universitas Merdeka Malang, sebagai bentuk keperdulian kampus pada kelancaran pelaksanaan Tri Darma Perguruan Tinggi dan mewujudkan kampus sebagai pusat kegiatan penelitian dan pengabdian masyarakat.

\section{DAFTAR PUSTAKA}

Antara, M., \& Arida, N. S. (2015). Panduan pengelolaan desa wisata berbasis potensi lokal. Konsorium Riset Pariwisata Universitas Udayana. Retrieved from: https://simdos.unud.ac.id/uploads/file_ penelitian_1_dir/bb9746610 f49ba39f27856edb95362f9.pdf

Campbell, L., \& Vainio-Mattila, A. (2003). Participatory development and community-based conservation: Opportunities missed for lessons learned? Human Ecology, 31(3), 417-437. https://doi.org/10.1023/A:1025071822388

Hamzah, Y. I. (2013). Potensi media sosial sebagai sarana promosi interaktif bagi pariwisata Indonesia. Jurnal Kepariwisataan Indonesia, 8(3), 1-9. Retrieved from: http://www.kemenpar.go.id/ userfiles/JKI Vol_8 No_3 2013 - Potensi Media Sosial Sebagai Sarana Promosi Interaktif Bagi Pariwisata Indonesia.pdf

Henderson, J. C. (2007). Managing Tourism Crises. Oxford: Elsevier.

Kementerian Pariwisata Republik Indonesia. (2018). Panduan Pengembangan Homestay Desa Wisata untuk Masyarakat (3rd ed.). Indonesia: Kementerian Pariwisata Republik Indonesia.

Lazuardi, M., \& Triady, M. S. (2015). Ekonomi Kreatif: Rencana Pengembangan Kuliner Nasional 20152019. Indonesia: PT Republik Solusi.

Lembaga Penyelidikan Ekonomi dan Masyarakat FEB Universitas Indonesia. (2018). Kajian Dampak Sektor Pariwisata Terhadap Perekonomiann Indonesia.

Rofieq, M., Poerwanto, A., \& Budiyanto, H. (2017). Pelatihan desain kemasan produk untuk UMKM kerajinan, kuliner dan posdaya. Abdimas: Jurnal Pengabdian Masyarakat Unmer Malang, 2(2), 1-6. https://doi.org/10.26905/abdimas.v2i2.1810

Sari, N. (2018). Pengembangan ekonomi kreatif bidang kuliner khas Daerah Jambi. Jurnal Sains Sosio Humaniora, 2(1), 51-60. https://doi.org/10.22437/jssh.v2i1.5281

Soekarya, T. (2011). Peningkatan Ekonomi Kerakyatan Melalui Pengembangan Desa Wisata (suatu masukan untuk pengembangan diKakaskasen Dua, Teritip dan Punten). Kementerian Kebudayaan dan Pariwisata.

UNCTAD. (2018). Creative Economoy Outlook and Country Profiles. United Nations.

Widayati, S., Setyawan, P. E., \& Sonalitha, E. (2019). Panorama Jurang Toleh, Jatiguwi, Sumberpucung, Kabupaten Malang, Jawa Timur. Abdimas: Jurnal Pengabdian Masyarakat Unmer Malang, 4(2), 12-17. https://doi.org/10.26905/abdimas.v4i2.3804 
ABDIMAS: Jurnal Pengabdian Masyarakat Universitas Merdeka Malang Volume 6, No 2, May 2021: 209-220

Wikantiyoso, R., Cahyaningsih, D. S., Sulaksono, A. G., \& Widayati, S. (2019). Empowerment and strengthening of community resilience in developing ecotourism destination in Grangsil Hamlet, Malang Regency, Indonesia. Conference: 3rd Endinamosis 2019 International Conference on "Empowering Rural Areas in the Industry 4.0 Era," 11.

Yusadi, R., Waluyo, B. S., \& Setyono, D. A. (2018). Rencana aksi pengembangan industri kreatif kuliner berbasis media online di Kota Malang. Jurnal Tata Kota dan Daerah, 10(2), 91-98. http://dx.doi.org/10.21776/ub.takoda.2018.010.02.4 